\section{Mummy Berry Blight Resistance in Rabbiteye Blueberry Cultivars}

\author{
M.K. Ehlenfeldt ${ }^{1}$ and A.W. Stretch ${ }^{2}$ \\ U.S. Department of Agriculture, Agricultural Research Service, Rutgers \\ Blueberry and Cranberry Research Center, 125A Lake Oswego Road, \\ Chatsworth, NJ 08019
}

Additional index words. Vaccinium corymbosum, V. ashei, Monilinia vaccinii-corymbosi, highbush blueberry

\begin{abstract}
The resistance of 26 rabbiteye blueberry (Vaccinium ashei Reade) cultivars to the blighting phase of mummy berry disease was evaluated under controlled conditions. In 1997, blight levels ranged from $31 \%$ to $84 \%$, and averaged $61.3 \%$ across all cultivars. In 1998, blight levels ranged from $71 \%$ to $99 \%$, and averaged $89.9 \%$. Several cultivars, including 'Coastal', 'Delite', 'Centurion', 'Walker', 'Callaway', and 'Garden Blue', exhibited significantly lower levels of mummy berry blight infection in both years. Blighting levels were significantly correlated with new shoot length in 1997, but not in 1998 . Rabbiteye blueberry, in general, is less resistant to mummy berry blight than is highbush blueberry ( $V$. corymbosum $L$.), but several options exist for potential improvement.
\end{abstract}

Mummy berry, caused by the fungus Monilinia vaccinii-corymbosi (Reade) Honey is the most important fungal disease of blueberry in North America (Eck, 1988). The fungus overwinters on the soil surface as a pseudosclerotium or mummy, and apothecia develop from the mummy in early spring (Batra, 1983). Primary infection occurs when ascospores forcibly ejected from the apothecium infect noncuticularized leaf, stem, and flower-buds, causing a blighting of the new growth. In the secondary infection phase, conidia produced on the surface of blighted tissue are carried by wind and pollinating insects to stigmas where they germinate and grow down the style into the ovary. Fungal tissue colonizes and fills the locules of the fruit, with no visible exterior symptoms until near harvest, when infected berries turn a salmon or cream color, begin to dry up, and drop to the ground.

Several studies have documented levels of resistance to $M$. vaccinii-corymbosi in highbush blueberry cultivars (Nelson and Bittenbender, 1971; Pepin and Toms, 1969; Varney and Stretch, 1966). The most methodical screening was an evaluation of 52 highbush blueberry cultivars, utilizing concentrated inoculum in a nursery-type setting (Stretch et al., 1995). Several cultivars with good horticultural quality and high levels of resistance were identified. Ehlenfeldt et al. (1996), working with a subset of 48 of the 52 cultivars evaluated by Stretch et al. (1995), examined plant phenology and found a significant correlation $(r=0.74)$ between blight incidence and

Received for publication 7 Sept. 1999. Accepted for publication 11 Apr. 2000. The cost of publishing this paper was defrayed in part by the payment of page charges. Under postal regulations, this paper therefore must be hereby marked advertisement solely to indicate this fact.

${ }^{1}$ Research Geneticist. E-mail address: mehlenfe@ ag.gov

${ }^{2}$ Plant Pathologist. average shoot length during the first week of ascospore release. Mean length of new shoots of the eight most susceptible cultivars was $32 \%$ to $91 \%$ greater than the mean for all cultivars for the first week, while that of the eight most resistant cultivars was $18 \%$ to $42 \%$ shorter than the mean. These differences suggested that some cultivars may derive a measure of resistance to blighting by disease avoidance. Ehlenfeldt et al. (1996) also noted, however, that other cultivars appeared to have true biochemical resistance. Shoot growth of 'Duke', a more recently released and widely planted cultivar, was comparable with that of some of the most susceptible cultivars, yet this cultivar was among the most blight-resistant.

In a later study, Ehlenfeldt et al. (1997) manipulated shoot elongation in resistant cultivars to evaluate whether blighting resistance was a result of avoidance. This study included five blight-resistant cultivars, 'Jersey', 'Bluejay', 'Duke', 'Stanley', and 'Darrow' (Stretch et al., 1995), and the highly susceptible cultivars Blueray and Croatan. In the highly susceptible cultivars, susceptibility was highest when shoot length was least, and decreased as shoot length increased. In contrast, resistant cultivars exhibited either slight or no increases in susceptibility as shoot lengths increased. Ehlenfeldt et al. (1997) concluded that such cultivars exhibited both avoidance and biochemical resistance. 'Duke' resembled susceptible cultivars in that blighting decreased steadily as shoot length increased, although blight levels were much lower overall.

Fruit susceptibility to mummy berry was also investigated by Stretch and Ehlenfeldt (1998). No correlation was found between blight resistance and resistance to fruit infection $(r=0.15)$, but several cultivars appeared to offer good resistance to both phases.

We are interested in breeding for resistance, not only in northern and southern highbush, but also in rabbiteye, which has long been recognized as being highly susceptible to mummy berry blighting (Austin, 1994;
Eck, 1988). This phase can severely damage both the vegetative shoots and the floral buds (Austin, 1994; Demaree and Wilcox, 1947; Milholland and Meyer, 1984). Although susceptibility is well documented, there has been no systematic survey that included significant numbers of modern and obsolete cultivars, and no reports exist of relative susceptibility of rabbiteye flowers to conidial infection. Bertrand (1985) documented such susceptibility in rabbiteye fruit, but made no quantitative cultivar comparisons.

Our goals were to: 1) evaluate a large number of rabbiteye cultivars under controlled conditions; 2) determine whether any measurable level of blight resistance was present; and 3) determine whether mummy berry blight infection was related to relative rates of shoot growth.

\section{Materials and Methods}

In 1997, a group of 26 rabbiteye cultivars, representing many commonly grown cultivars and numerous older cultivars, was assembled as the core screening population (Table 1). Four additional cultivars, 'Bluegem', 'Clara', 'Homebell', and 'Myers', were included in 1998 as plants became available. The tests were conducted in a randomized complete-block design, generally with five replicates and one plant per cultivar per replicate. 'Homebell' and 'Myers' were evaluated in only three and four replicates, respectively. The plants were potted in $2.84-\mathrm{L}$ pots in a 1 sand : 1 peat mix (by volume) and the pots were arranged in a $5 \times 6$ grid pattern in each replicate, with $0.45 \mathrm{~m}$ between plants. The strains of $M$. vacciniicorymbosi used were northern types collected from the Rutgers Blueberry and Cranberry Research Center at Chatsworth, N.J. Pseudosclerotia of $M$. vaccinii-corymbosi were collected in September from the field, transplanted into soil-filled 2.84-L plastic pots, and overwintered in cold frames. At the start of each test, pots containing pseudosclerotia with apothecia were placed at evenly spaced intervals within and around the periphery of the experimental area to provide an even distribution of inoculum. To enhance the infection process, the entire plot received supplemental misting for $1 \mathrm{~h}$ every evening during ascospore release (the volume applied was $\approx 5 \mathrm{~L} / \mathrm{m}^{2}$ per day).

In 1997, the trial was set up on 7 Apr. Shoot lengths from bud base to leaf tip were measured on five tagged shoots per plant on $8 \mathrm{Apr}$. and averaged for each plant. Efforts were made to tag five sequential shoots on a branch to get an accurate representation of both long terminal shoots and shorter subterminal shoots. In cases where tagged shoots were broken or damaged during the course of the experiment, new shoots were selected at random and tagged. Plants were examined for blighted shoots on eight dates between 2 May and 30 May 1997. At each inspection, blighted shoots were tabulated and removed. At the end of the blight period, remaining healthy shoots were counted on each plant so that the percentage of blighted shoots could be calculated. In 1998, the trial 
Table 1. Percentage of blighted vegetative shoots from primary infection by ascospores of Monilinia vaccinii-corymbosi in rabbiteye blueberry cultivars.

\begin{tabular}{|c|c|c|c|c|c|}
\hline \multirow[b]{2}{*}{ Cultivar } & \multicolumn{3}{|c|}{ Blight (\% $(\% \mathrm{SE})$} & \multicolumn{2}{|c|}{ Rank } \\
\hline & 1997 & 1998 & 2-year avg & 1997 & 1998 \\
\hline Coastal & $34.7 \pm 4.9$ & $71.0 \pm 9.0$ & $52.9 \mathrm{a}^{\mathrm{z}}$ & 3 & 1 \\
\hline Delite & $33.3 \pm 9.9$ & $77.3 \pm 8.2$ & $55.3 \mathrm{ab}$ & 2 & 5 \\
\hline Centurion & $30.9 \pm 10.7$ & $85.6 \pm 5.7$ & $58.2 \mathrm{ab}$ & 1 & 8 \\
\hline Walker & $43.1 \pm 5.5$ & $75.0 \pm 7.8$ & $59.1 \mathrm{ab}$ & 4 & 3 \\
\hline Callaway & $44.5 \pm 6.2$ & $76.1 \pm 6.5$ & $60.3 \mathrm{ab}$ & 5 & 4 \\
\hline Garden Blue & $48.0 \pm 10.3$ & $73.2 \pm 6.7$ & $60.6 \mathrm{ab}$ & 7 & 2 \\
\hline Premier & $44.8 \pm 13.9$ & $88.2 \pm 3.0$ & $66.5 \mathrm{bc}$ & 6 & 10 \\
\hline Black Giant & $50.7 \pm 14.4$ & $84.2 \pm 10.1$ & $67.5 \mathrm{bcd}$ & 9 & 6 \\
\hline Bluebelle & $50.5 \pm 7.3$ & $85.1 \pm 4.1$ & $67.8 \mathrm{bcd}$ & 8 & 7 \\
\hline Baldwin & $58.5 \pm 11.2$ & $95.2 \pm 1.2$ & 76.9 cde & 11 & 15 \\
\hline Woodard & $58.2 \pm 10.5$ & $98.9 \pm 0.7$ & $78.6 \mathrm{cdef}$ & 10 & 25 \\
\hline Chaucer & $61.8 \pm 9.3$ & $97.2 \pm 1.5$ & $79.5 \mathrm{def}$ & 12 & 22 \\
\hline Choice & $68.0 \pm 7.9$ & $95.3 \pm 1.5$ & $81.6 \mathrm{ef}$ & 13 & 17 \\
\hline Powderblue & $72.4 \pm 5.3$ & $91.0 \pm 5.3$ & 81.7 ef & 19 & 11 \\
\hline Brightwell & $70.2 \pm 4.6$ & $95.1 \pm 2.1$ & $82.6 \mathrm{ef}$ & 17 & 14 \\
\hline Southland & $68.3 \pm 5.8$ & $98.1 \pm 0.8$ & $83.2 \mathrm{ef}$ & 14 & 23 \\
\hline Snowflake & $69.8 \pm 4.2$ & $96.9 \pm 0.6$ & 83.4 ef & 16 & 20 \\
\hline Climax & $68.6 \pm 16.3$ & $98.7 \pm 0.8$ & $83.6 \mathrm{ef}$ & 15 & 24 \\
\hline Aliceblue & $70.3 \pm 3.1$ & $97.2 \pm 0.5$ & 83.8 ef & 18 & 21 \\
\hline Ethel & $76.2 \pm 11.1$ & $93.2 \pm 4.1$ & 84.7 ef & 22 & 13 \\
\hline Windy & $78.0 \pm 7.2$ & $91.4 \pm 3.6$ & 84.7 ef & 23 & 12 \\
\hline Austin & $81.5 \pm 4.9$ & $87.9 \pm 10.9$ & 84.7 ef & 25 & 9 \\
\hline Beckyblue & $74.0 \pm 8.9$ & $96.2 \pm 2.1$ & $85.1 \mathrm{ef}$ & 20 & 19 \\
\hline Briteblue & $78.3 \pm 6.8$ & $95.6 \pm 1.2$ & 87.0 ef & 24 & 18 \\
\hline Tifblue & $75.8 \pm 4.1$ & $99.4 \pm 0.2$ & 87.6 ef & 21 & 26 \\
\hline Bonita & $83.8 \pm 8.8$ & $95.2 \pm 2.1$ & $89.5 \mathrm{f}$ & 26 & 16 \\
\hline Mean & 61.3 & 89.9 & 75.6 & & \\
\hline
\end{tabular}

${ }^{2}$ Mean separation within columns by LSD, $P=0.05$.

was set up on 26 Mar., shoot lengths were measured on 29 Mar., and blighted shoots were counted six times between $21 \mathrm{Apr}$. and 14 May. At the end of the experiment, nonblighted shoots were counted as before.

Data (mean shoot length during the first full week of the experiment, the period during which apothecia were most prevalent) were analyzed by analysis of variance using MSTAT-C statistical analysis software (Michigan State Univ., E. Lansing).

\section{Results and Discussion}

Year was a significant source of variation for blighting $(\mathrm{F}=30.58, P=0.0006)$. The mean blight value across all cultivars was $61.3 \%$ in 1997 vs. $89.9 \%$ in 1998 . Cultivar $\times$ year interactions were nonsignificant $(\mathrm{F}=1.50$, $P=0.07)$. Cultivar was also a significant source of variation $(\mathrm{F}=6.71, P \leq 0.0001)$. Blight levels ranged from $30.9 \%$ ('Centurion') to $83.8 \%$ ('Bonita') in 1997, and from $71.0 \%$ ('Coastal') to 99.4\% ('Tifblue') in 1998 (Table 1). 'Coastal', 'Delite', 'Centurion', 'Walker', 'Callaway', and 'Garden Blue' had the lowest infection levels, with 2-year average values ranging from $52.9 \%$ to $60.6 \%$ (Table 1 ). The group with highest infection levels across the 2 years included 16 of the 26 cultivars; and infection ranged from $78.6 \%$ in 'Woodard' to $89.5 \%$ in 'Bonita'. The rankings across the 2 years were significantly correlated $(r=0.746$, $P \leq 0.0001)$. The rankings were relatively consistent for the nine least-susceptible cultivars, but more variable for many of the more susceptible cultivars. By comparison, in a previous study with 46 highbush cultivars in 1993-95, the lowest blight value was $2.9 \%$, the highest was $64.8 \%$, and the overall mean was $26.0 \%$ (Ehlenfeldt et al., 1996). Thus, no rabbiteye cultivar possessed the high levels of blight resistance of highbush selections under the high inoculum rates used.

Several cultivars were evaluated in only 1 year, and of these, two were present in reduced numbers. These cultivars were not analyzed with the others, but the values offer some interesting prospects. Data for 'Bluegem' (82.4\%), 'Clara' (92.7\%), and 'Homebell' (95.9\%, only four plants) were all within the range of those for many of the susceptible cultivars, but 'Myers' (three plants) had the lowest value $(58.8 \%)$ observed in 1998 .

Many rabbiteye blueberry cultivars are closely related. In particular, many of the earlier cultivars have mainly four native selections in their pedigrees, 'Black Giant', 'Clara', 'Ethel', and 'Myers'. Of these founding native selections, 'Black Giant' and 'Ethel' were included in the replicated evaluations, while 'Clara' and 'Myers' were present in reduced numbers. 'Black Giant' ranked in the better third of the cultivars with an average value of $67.5 \%$. In 1998, 'Myers' had a blight rating of $58.8 \%$, the lowest recorded in that year. Among cultivars surveyed, only two, 'Coastal' and 'Callaway', had both 'Black Giant' and 'Myers' as parents. Both of these cultivars were among the most resistant, with values of $52.9 \%$ and $60.3 \%$, respectively. 'Myers' is also a parent of 'Garden Blue' $(60.6 \%)$, which was also ranked among the most resistant across the 2 years. In contrast, 'Homebell', a sibling of 'Coastal', evaluated only in 1998, was in the susceptible group with a blight rating of $95.9 \%$. Thus, the progenies of the cross 'Myers' $x$ 'Black Giant' have the potential to segregate into both resistant ('Coastal') and susceptible types ('Homebell'). 'Bluebelle', 'Woodard', 'Climax', and 'Briteblue' all have 'Callaway' $(60.3 \%)$ and 'Ethel' (84.7\%) as parents. Their reactions to blighting, averaged across 2 years, ranged from $67.8 \%$ for 'Bluebelle' to $87.0 \%$ for 'Briteblue'. Thus, significant variability also appears among the progeny of this cross. Among the other better selections, 'Delite' $(55.3 \%)$ is a cross of 'Bluebelle' $(67.8 \%) \mathrm{x}$ $\mathrm{T}-15$, 'Centurion' $(58.2 \%)$ is a cross of W-4 $\mathrm{X}$ 'Callaway' (60.3\%), and 'Walker' (59.1\%) is a native selection.

In 1997, a significant positive correlation was observed between final percentage of blight and shoot length during the first week of ascospore release $(r=0.193, P=0.028)$ (data not shown). The average shoot length recorded across all cultivars during this period was 14.4 $\mathrm{mm}$, and blighting was only $61.3 \%$. In contrast, in 1998, a positive, but nonsignificant, correlation was observed between final percentage of blight and shoot length during a comparable period ( $r=0.047, P=0.593)$. In 1998 , shoot length during the first week of ascospore release averaged only $8.3 \mathrm{~mm}$, but final percentage of blight was 90.4. In 1998, plants appeared to be in optimum condition for infection, and the high infection rates obscured any effect of shoot length. Longer shoots, lower infection rates, and a significant positive correlation in 1997 suggest that conditions were less ideal for infection; this perhaps allowed better resolution of the relationship between shoot length and susceptibility. Based on these results, shoot length does not appear to be a consistent predictor of susceptibility in rabbiteye. The differences in susceptibility between 1997 and 1998 may have been due to qualitative differences in tissue development and/or damage. Hildebrand and Braun (1991) noted increased susceptibility in tissue subjected to freezing damage. We have also observed that tender tissue was more susceptible when it developed under high rather than lower humidity.

Many opportunities exist to introduce improved mummy berry resistance into rabbiteye blueberry. These include the production of 5x cultivars such as 'Pearl River' (Spiers and Gupton, 1997) via rabbiteye $x$ highbush crosses, backcrosses of pentaploids to rabbiteye, $V$. constablaei $\mathrm{x}$ rabbiteye crosses (Lyrene, 1993), and crosses of synthesized $6 \mathrm{x}$ highbush $\mathrm{x}$ rabbiteye (Ehlenfeldt and Vorsa, 1994). Depending upon the mode of inheritance of resistance, all of these methods may provide an avenue for the transmission of significant blight resistance into rabbiteye blueberry.

\section{Literature Cited}

Austin, M.E. 1994. Rabbiteye blueberries: Development, production, and marketing. AGSCIENCE, Auburndale, Fla.

Batra, L.R. 1983. Monilinia vaccinii-corymbosi (Sclerotiniaceae): Its biology on blueberry and comparison with related species. Mycologia 75:131-152. 
Bertrand, P. 1985. Two potentially damaging diseases of rabbiteye blueberries in Georgia. Phytopathology 75:1314. (Abstr.)

Demaree, J.B. and M.S. Wilcox. 1947. Fungi pathogenic to blueberries in the eastern United States. Phytopathology 37:487-506.

Eck, P. 1988. Blueberry science. Rutgers Univ. Press, New Brunswick, N.J.

Ehlenfeldt, M.K., A.W. Stretch, and V. Brewster. 1996. Genetic and morphological factors affecting mummy berry blight resistance in highbush blueberry cultivars. HortScience 31:252-254.

Ehlenfeldt, M.K., A.W. Stretch, and J.S. Lehman. 1997. A further examination of the relationship between shoot length and mummy berry blight resistance in highbush blueberry cultivars. HortScience 32:884-887.

Ehlenfeldt, M.K. and N. Vorsa. 1994. The genera- tion, evaluation and utilization of hexaploid progeny from $3 \times$ x $3 x$ crosses of highbush blueberry: Germplasm transfer and 2 n gametes in blueberry. Acta Hort. 346:95-102.

Hildebrand, P.D. and P.G. Braun. 1991. Factors affecting infection of lowbush blueberry by ascospores of Monilinia vaccinii-corymbosi. Can. J. Plant Path. 13:232-240.

Lyrene, P.M. 1993. Some problems and opportunities in blueberry breeding. Acta Hort. 346:63-71.

Milholland, R.D. and J.R. Meyer. 1984. Diseases and arthropod pests of blueberries. Bul. 468, North Carolina Agr. Res. Serv.

Nelson, J. and H.C. Bittenbender. 1971. Mummy berry disease occurrence in a blueberry selection test planting. Plant Dis. Rptr. 55:651-653. Pepin, H.S. and H.N.W. Toms. 1969. Susceptibility of highbush blueberry varieties to Monilinia vaccinii-corymbosi. Phytopathology 59:18761878.

Spiers, J.M. and C.L. Gupton. 1997. 'Jubilee', 'Magnolia', and 'Pearl River' southern highbush blueberries. Acta Hort. 446:155-157.

Stretch, A.W. and M.K. Ehlenfeldt. 1998. Identifying sources of resistance to mummy berry and anthracnose in highbush blueberry. Acta Hort. 446:281-286.

Stretch, A.W., M.K. Ehlenfeldt, and V. Brewster. 1995. Mummy berry blight resistance in highbush blueberry cultivars. HortScience 30:589-591.

Varney, E.H. and A.W. Stretch. 1966. Diseases and their control, p. 236-279. In: P. Eck and N.F. Childers (eds.). Blueberry culture. Rutgers Univ. Press, New Brunswick, N.J. 